\title{
COMPARATIVE HEAVY METALS CONCENTRATION IN WATER COLUMN, SEDIMENTS, CHRYSICHTHYS NIGRODIGITATUS (SILVER CATFISH) AND MACROBRACHIUM MACROBRACHION (BRACKISH WATER PRAWN) FROM BADAGRY CREEK AND OLOGE LAGOON IN NIGERIA
}

\author{
Oluwatoyin J. Aderinola ${ }^{1}$, Gabriel O. Mekuleyi*,2, Abosede A. Adu ${ }^{3}$ \\ ${ }^{1}$ Department of Zoology and Environmental Biology, Lagos State University, Ojo, Lagos, Nigeria. \\ ${ }^{2}$ Department of Fisheries, Lagos State University, Ojo, Lagos, Nigeria \\ ${ }^{3}$ Department of Botany, Lagos State University, Ojo, Lagos, Nigeria \\ *Corresponding Author
}

DOI: 10.46609/IJAER.2020.v06i03.011 URL: https://doi.org/10.46609/IJAER.2020.v06i03.011

\begin{abstract}
The present study investigated the concentration of heavy metals (lead $(\mathrm{Pb})$, cadmium $(\mathrm{Cd})$, chromium $(\mathrm{Cr})$, copper $(\mathrm{Cu})$, zinc $(\mathrm{Zn})$, and iron $(\mathrm{Fe})$ in water, sediments, Chrysichthys nigrodigitatus and Macrobrachium macrobrachion from Badagry Creek and Ologe Lagoon, between June and November, 2016. Water, sediment, 90 C. nigrodigitatus and 110 M. macrobrachion were collected and digested using standard method. Fe $\left(178.97 \pm 15.48 \mathrm{mgL}^{-1}\right)$ and Zn $\left(299.63 \pm 152.17 \mathrm{mgL}^{-1}\right)$ concentrations in water of Ologe Lagoon was higher $(\mathrm{p}<0.05)$ than that recorded in Badagry Creek $\left(138.16 \pm 39.49 \mathrm{mgL}^{-1}, 295.71 \pm 9.33 \mathrm{mgL}^{-1}\right)$. Cd concentration in sediment from Badagry Creek $\left(7.96 \pm 4.45 \mathrm{ugg}^{-1}\right)$ was significantly $(\mathrm{p}<0.05)$ higher than that from Ologe Lagoon $\left(5.98 \pm 2.48 \mu \mathrm{gg}^{-1}\right) . \mathrm{Cu}, \mathrm{Zn}$ and Fe $\left(7.94 \pm 2.58 \mu \mathrm{gg}^{-1}, 1543.78 \pm 315.04 \mu \mathrm{gg}^{-1}\right.$ and $\left.6992.70 \pm 3905.63{\mu \mathrm{gg}^{-1}}\right)$ respectively in the sediment from Ologe Lagoon were significantly higher than values $\left(4.75 \pm 1.28 \mu \mathrm{gg}^{-1}, 738.29 \pm 87.89 \mu \mathrm{gg}^{-1}\right.$ and $\left.5330.40 \pm 954.31 \mu \mathrm{gg}^{-1}\right)$ recorded in sediment from Badagry Creek. The $\mathrm{Zn}$ and Fe content respectively in M. macrobrachion from Ologe Lagoon $\left(42.19 \pm 6.02 \mu \mathrm{gg}^{-1}, 48.77 \pm 24.69 \mu \mathrm{g} \mathrm{g}^{-1}\right)$ was higher $(\mathrm{p}<0.05)$ than that from Badagry Creek $\left(21.18 \pm 14.28 \mu \mathrm{gg}^{-1}, 38.74 \pm 29.09 \mu \mathrm{gg}^{-1}\right)$ while the concentration of Fe in $C$. nigrodigitatus from Badagry Creek $\left(32.61 \pm 13.41 \mu \mathrm{g} \mathrm{g}^{-1}\right)$ was higher than that from Ologe Lagoon $\left(25.54 \pm 12.14 \mu \mathrm{g} \mathrm{g}^{-1}\right)$. The $\mathrm{Cu}, \mathrm{Zn}, \mathrm{Fe}$ and $\mathrm{Cr}$ in the water column, and $\mathrm{Zn}$ and $\mathrm{Fe}$ in sediment, C. nigrodigitatus and $M$. macrobrachion from Ologe Lagoon and Badagry Creek
\end{abstract}


exceeded WHO permissible limits. The results indicated that both water bodies are contaminated with heavy metals although more prominent in Ologe Lagoon. Therefore, indiscriminate discharging of untreated effluents into Badagry creek and Ologe Lagoon should be cautioned.

Keywords: Heavy metals, Fish, Water, Sediment, Creek, Lagoon, Nigeria

\section{INTRODUCTION}

The West African coastline is richly endowed with numerous rivers, coastal lagoon, estuaries, creeks, inland lakes and swamps. These natural aquatic environments sustain a multitude of flora and fauna, and serves as means of livelihood for coastal communities. In addition, they serve various essential roles in water transportation, energy generation, sand dredging and drainage [1]. Ologe Lagoon and Badagry creek are among the five main water bodies found in Lagos Western-Nigeria and like other coastal waters, they serve as sink for domestic and industrial wastes [2].

Fish and Shellfish are major part of the human diet, especially in coastal areas, which supplies all essential elements required for life processes in a balanced manner [3]. The health effect in human due to continuous consumption of food contaminated with heavy metals and the extent of this contamination depends on several complex factors, such as metabolic and homeostatic mechanisms operating in the type of organism in question[4]. Therefore, the present study aimed to investigate the level of heavy metals in water column, sediments, silver catfish (Chrysichthys nigrodigitatus) and brackish water prawn (Macrobrachium macrobrachion) in both Badagry creek and Ologe Lagoon.

\section{MATERIAL AND METHODS}

\subsection{Study area}

Badagry Creek and Ologe Lagoon (Fig.1) are part of the continuous system of Lagoon and creeks along the coast of Nigeria. Badagry creek, the larger of the two sampling water bodies lies within longitude $2^{\circ} 42^{\prime} \mathrm{E}$ and $3^{\circ} 42^{\prime} \mathrm{E}$ and stretches between latitude $6^{\circ} 22^{\prime} \mathrm{N}$ and $6^{\circ} 42^{\prime} \mathrm{N}$, sharing boundary with Republic of Benin. The creek is about $60 \mathrm{~km}$ long and $3 \mathrm{~km}$ wide. Ologe Lagoon on the other hand is situated adjacent to Badagry creek between latitude $6^{0} 26 \mathrm{~N}$ and longitude 30 $01^{\prime} \mathrm{E}$ to $3^{0} 07^{\prime} \mathrm{E}$, and the Lagoon has a surface area of $9 \mathrm{~km}^{2}$ and is the smallest of the Lagoons in south western Nigeria. 


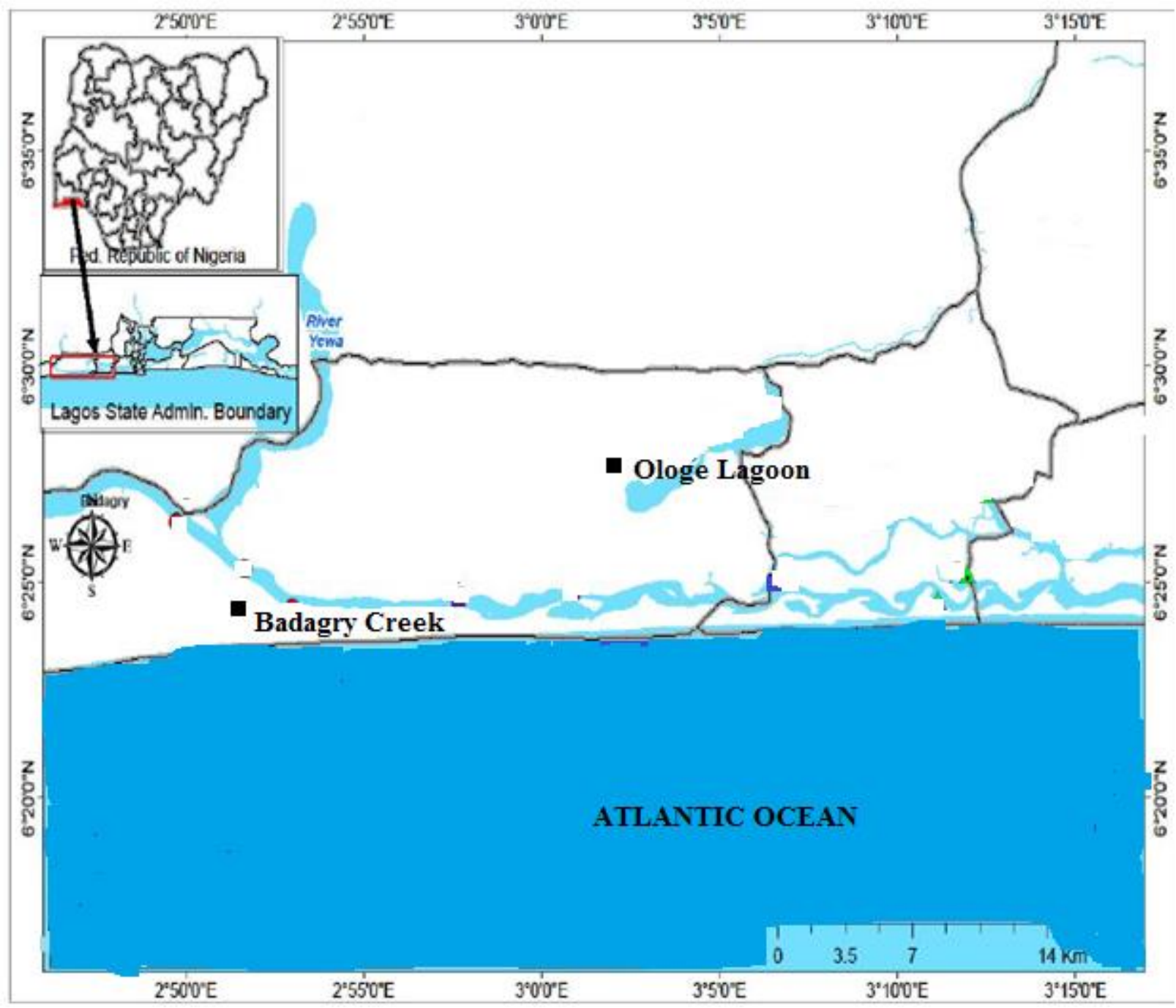

Figure 1: Map of Ologe Lagoon and Badagry Creek in Lagos,Nigeria

\subsection{Samples Collection}

A total of 90 specimens of Chrysichthys nigrodigitatus (silver catfish) and 110 Macrobrachium macrobrachion (brackish water prawn) were collected from both Badagry creek and Ologe Lagoon between June and October 2016. Water samples were also collected at a depth of about $15 \mathrm{~cm}$ below water surface in $250 \mathrm{ml}$ plastics bottles with screw lid. Before sampling, the bottles were treated by soaking them in $10 \%$ nitric acid (Baker Instra- Analyzed ${ }^{\circledR}$ Reagent) for $24 \mathrm{~h}$ after which they were rinsed with distilled water. Immediately after sample collection, $5 \mathrm{ml}$ nitric acid (Baker Instra- Analyzed ${ }^{\circledR}$ Reagent) was added to the water samples to reduce adsorption of metals onto the walls of the plastic bottles [5]. Sediment samples were collected using a 2 inch 
International Journal of Agriculture and Environmental Research

ISSN: 2455-6939

Volume: 06, Issue: 03 "May-June 2020"

diameter steel pipe pressed through the water column. The sediment samples collected were placed into polythene bags which have been pre-treated with $10 \%$ nitric acid. All samples (fish, prawn, water and sediment) were digested in accordance to standard procedure [5]. Heavy metals $(\mathrm{Pb}, \mathrm{Cd}, \mathrm{Cr}, \mathrm{Cu}, \mathrm{Zn}$ and $\mathrm{Fe})$ concentration in the digested water, sediment and fish samples were analyzed with atomic absorption spectrophotometer (Buck scientific 210 VGP model, USA). Metal levels in water were expressed in $\mathrm{mgL}^{-1}$ while that of sediment, silver catfish and brackish water prawn were expressed in $\mu \mathrm{gg}^{-1}$ dry weight.

\subsection{Statistical Analysis}

Metals variation was tested by t-test and where there are significant variations fisher's least significant difference was used to separate the means. In all cases, the level of significance was set at $\mathrm{p}<0.05$.

\section{RESULTS}

The respective concentrations of $\mathrm{Pb}\left(0.00 \pm 0.00 \mathrm{mgL}^{-1}\right)$ obtained in the water samples from Badagry Creek and Ologe Lagoon, and Cd in water from Badagry Creek $\left(0.00 \pm 0.00 \mathrm{mgL}^{-1}\right)$ and Ologe Lagoon $\left(0.002 \pm 0.002 \mathrm{mgL}^{-1}\right)$ are not significantly different $(\mathrm{p}>0.05)$. Similarly, the values of $\mathrm{Cu}\left(12.87 \pm 2.31 \mathrm{mgL}^{-1}\right.$ and $\left.13.33 \pm 5.17 \mathrm{mgL}^{-1}\right)$ and $\mathrm{Cr}\left(1.65 \pm 0.33 \mathrm{mgL}^{-1}\right.$ and $\left.0.72 \pm 0.01 \mathrm{mg} \mathrm{L}^{-1}\right)$ in water samples from Badagry Creek and Ologe Lagos respectively, showed no significant ( $p>0.05$ ) differences. However, the values of $\mathrm{Fe}$ and $\mathrm{Zn}$ concentrations respectively in water of Ologe Lagoon $\left(178.97 \pm 15.48 \mathrm{mgL}^{-1}, 299.63 \pm 152.17 \mathrm{mgL}^{-1}\right)$ was higher $(\mathrm{p}<0.05)$ than that recorded in Badagry Creek $\left(138.16 \pm 39.49 \mathrm{mgL}^{-1}, 295.71 \pm 9.33 \mathrm{mgL}^{-1}\right.$ ) as shown in Table 1 .

The concentration of the $\mathrm{Pb}$ recorded in sediment (Table 1) was $1.11 \pm 0.13 \mu \mathrm{gg}^{-1}$ in Ologe Lagoon and $0.70 \pm 0.17{\mu g^{-1}}^{-1}$ in Badagry Creek while the concentration of $\mathrm{Cr}$ in the sediment was $4.87 \pm 4.25 \mu \mathrm{gg}^{-1}$ in Ologe Lagoon and $4.96 \pm 1.39 \mu \mathrm{gg}^{-1}$ in Badagry Creek. There was no significant $(\mathrm{p}>0.05)$ difference between the $\mathrm{Pb}$ and $\mathrm{Cr}$ concentrations recorded from the two sampling areas. On the contrary, Cd results showed that the concentration of sediment in Badagry Creek $\left(7.96 \pm 4.45 \mu \mathrm{gg}^{-1}\right)$ was significantly $(\mathrm{p}<0.05)$ higher than that from Ologe Lagoon $\left(5.98 \pm 2.48 \mu \mathrm{gg}^{-1}\right)$. Also, the values of $\mathrm{Cu}, \mathrm{Zn}$ and $\mathrm{Fe}\left(7.94 \pm 2.58 \mu \mathrm{gg}^{-1}, 1543.78 \pm 315.04 \mu_{\mathrm{gg}^{-1}}\right.$ and $6992.70 \pm 3905.63 \mu \mathrm{gg}^{-1}$ )respectively in the sediment from Ologe Lagoon were significantly higher than values $\left(4.75 \pm 1.28 \mu \mathrm{gg}^{-1}, 738.29 \pm 87.89 \mu \mathrm{gg}^{-1}\right.$ and $\left.5330.40 \pm 954.31 \mu \mathrm{gg}^{-1}\right)$ recorded in sediment from Badagry Creek as presented in Table 1.

The Silver catfish (SC) obtained from Badagry Creek had Pb concentration of $0.14 \pm 0.07 \mu \mathrm{gg}^{-1}$ while those from Ologe Lagoon had $0.12 \pm 0.06 \mu \mathrm{gg}^{-1}$. On the other hand, the concentration of $\mathrm{Pb}$ in Brackish water Prawn (BWP) at Ologe Lagoon and Badagry Creek respectively were $0.04+0.02 \mu \mathrm{gg}^{-1}$ and $0.02 \pm 0.02 \mu \mathrm{gg}^{-1}$ (Table 1$)$. There were no significant difference $(\mathrm{p}>0.05)$ 
between the concentration of $\mathrm{Pb}$ for both $\mathrm{SC}$ and BWP across the two stations. Similarly, the differences between concentration of $\mathrm{Cd}$ and $\mathrm{Cr}$ in SC respectively recorded in Badagry Creek $\left(0.29 \pm 0.34 \mu g^{-1}, 0.09 \pm 0.08 \mu \mathrm{gg}^{-1}\right)$ and Ologe Lagoon $\left(0.10 \pm 0.01 \mu \mathrm{gg}^{-1}, 0.07 \pm 0.02 \mu \mathrm{gg}^{-1}\right)$ were not significant $(\mathrm{p}>0.05)$. The result also showed that the concentration of $\mathrm{Cd}$ and $\mathrm{Cr}$ respectively in BWP at Ologe Lagoon $\left(0.06 \pm 0.08 \mu \mathrm{gg}^{-1}, 0.09 \pm 0.07 \mu \mathrm{gg}^{-1}\right)$ and Badagry Creek $(0.07 \pm 0.04 \mu \mathrm{g}$ $\left.\mathrm{g}^{-1,} 0.03 \pm 0.02 \mu \mathrm{g} \mathrm{g}^{-1}\right)$ did not differ $(\mathrm{p}>0.05)$.

The values of $\mathrm{Cu}$ in SC $\left(0.66 \pm 0.26 \mu \mathrm{gg}^{-1}\right.$ and $\left.1.05 \pm 0.32 \mu \mathrm{gg}^{-1}\right)$ and $\mathrm{BWP}\left(0.38 \pm 0.29 \mu \mathrm{gg}^{-1}\right.$ and $\left.0.80 \pm 0.18 \mu \mathrm{gg}^{-1}\right)$ from Badagry Creek and Ologe Lagos respectively, showed no significant ( $p>0.05$ ) differences (Table 1). The differences between the concentration of $\mathrm{Zn}$ recorded in silver catfish (SC) from Badagry Creek $\left(19.73 \pm 3.37 \mu \mathrm{gg}^{-1}\right)$ was not significantly $(\mathrm{p}>0.05)$ higher than that recorded in Ologe Lagoon $\left(19.48 \pm 4.86 \mu \mathrm{gg}^{-1}\right)$. On the other hand, the $\mathrm{Zn}$ content obtained in brackish water prawn (BWP) from Ologe Lagoon (42.19 $\pm 6.02 \mu \mathrm{gg}^{-1}$ ) was significantly higher $(\mathrm{p}<0.05)$ than that recorded in Badagry Creek $\left(21.18 \pm 14.28 \mu \mathrm{gg}^{-1}\right)$. In the same trend, the concentration of Fe in BWP was significantly higher $(\mathrm{p}<0.05)$ in Ologe Lagoon $\left(48.77 \pm 24.69 \mu \mathrm{g} \mathrm{g}^{-1}\right)$ than that from Badagry Creek $\left(38.74 \pm 29.09 \mu \mathrm{gg}^{-1}\right)$ while the concentration of Fe in SC from Badagry Creek $\left(32.61 \pm 13.41 \mu \mathrm{g} \mathrm{g}^{-1}\right)$ was higher than that of Ologe Lagoon $\left(25.54 \pm 12.14 \mu \mathrm{g} \mathrm{g}^{-1}\right)$ as shown in Table 1 . 
International Journal of Agriculture and Environmental Research

ISSN: 2455-6939

Volume: 06, Issue: 03 "May-June 2020"

Table 1: Heavy metals concentration in water, sediment, Silver catfish and brackish water prawn from Badagry creek and Ologe Lagoon in Nigeria

\begin{tabular}{|c|c|c|c|c|c|c|c|c|}
\hline \multicolumn{4}{|c|}{ BADAGRY CREEK } & \multicolumn{4}{|c|}{ OLOGE LAGOON } & \multirow[b]{2}{*}{ BWP } \\
\hline Metals & Water & Sediments & $\mathrm{SC}$ & BWP & Water & Sediment & $\mathrm{SC}$ & \\
\hline $\mathrm{Pb}$ & $0.00 . \pm 0.00^{\mathrm{a}}$ & $0.70 \pm 0.17^{\mathrm{a}}$ & $0.14 \pm 0.07^{\mathrm{a}}$ & $0.02 \pm 0.02^{\mathrm{a}}$ & $0.00 \pm 0.00^{\mathrm{a}}$ & $1.11 \pm 0.13^{\mathrm{a}}$ & $0.12 \pm 0.06^{\mathrm{a}}$ & $0.04 \pm 0.02^{\mathrm{a}}$ \\
\hline $\mathrm{Cd}$ & $0.00 \pm 0.00^{\mathrm{a}}$ & $7.96 \pm 4.45^{\mathrm{ab}}$ & $0.29 \pm 0.34^{\mathrm{a}}$ & $0.07 \pm 0.04^{\mathrm{a}}$ & $0.002 \pm 0.002^{\mathrm{a}}$ & $5.98 \pm 2.48^{b}$ & $0.10 \pm 0.01^{\mathrm{a}}$ & $0.06 \pm 0.08^{\mathrm{a}}$ \\
\hline $\mathrm{Cr}$ & $1.65 \pm 0.33^{b}$ & $4.96 \pm 1.39^{b}$ & $0.09 \pm 0.08^{\mathrm{a}}$ & $0.03 \pm 0.02^{\mathrm{a}}$ & $0.72 \pm 0.01^{\mathrm{b}}$ & $4.87 \pm 4.25^{\mathrm{b}}$ & $0.07 \pm 0.02^{\mathrm{a}}$ & $0.09 \pm 0.07^{\mathrm{a}}$ \\
\hline \multirow[t]{2}{*}{$\mathrm{Cu}$} & $12.87 \pm 2.31^{\mathrm{bc}}$ & $4.75 \pm 1.28^{b}$ & $0.66 \pm 0.26^{\mathrm{a}}$ & $0.38 \pm 0.29^{a}$ & $13.33 \pm 5.17^{\mathrm{bc}}$ & $7.94 \pm 2.58 \mathrm{a}$ & $1.05 \pm 0.32^{\mathrm{a}}$ & $0.80 \pm 0.18^{a}$ \\
\hline & & & & \multicolumn{5}{|c|}{$\mathrm{b}$} \\
\hline \multirow[t]{2}{*}{$\mathrm{Zn}$} & $295.71 \pm 9.33$ & $738.29 \pm 87.89^{\mathrm{ab}}$ & $19.73 \pm 3.37^{\mathrm{ab}}$ & $21.18 \pm 14.28^{b}$ & $299.63 \pm 152.17$ & $1543.78 \pm 3$ & $19.48 \pm 4.86^{\mathrm{ab}}$ & $42.19 \pm 6.02^{a b}$ \\
\hline & $\mathrm{c}$ & & & & $\mathrm{ac}$ & $15.04^{\mathrm{ad}}$ & & \\
\hline \multirow[t]{2}{*}{$\mathrm{Fe}$} & $138.16 \pm 39.4$ & $5330.40 \pm 954.31^{\mathrm{d}}$ & $32.60 \pm 13.4$ & $38.74 \pm 29.09^{\mathrm{cd}}$ & $178.97 \pm 15.48^{d}$ & $6992.70 \pm 3$ & $25.54 \pm 12.14$ & $48.77 \pm 24.69^{\mathrm{cc}}$ \\
\hline & $9^{d}$ & c & $1^{\mathrm{b}}$ & & $\mathrm{b}$ & $905.63^{\mathrm{dd}}$ & $\mathrm{bc}$ & \\
\hline
\end{tabular}


International Journal of Agriculture and Environmental Research

ISSN: 2455-6939

Volume: 06, Issue: 03 "May-June 2020"

\section{DISCUSSION}

The concentrations of lead $(\mathrm{Pb})$ and cadmium $(\mathrm{Cd})$ detected in water from both Ologe Lagoon and Badagry creek are very minute and the values are lower than WHO maximum permissible limit of $0.01 \mathrm{mgL}^{-1}$ and $0.003 \mathrm{mgL}^{-1}$ of $\mathrm{Pb}$ and $\mathrm{Cd}$ respectively. The values of $\mathrm{Pb}$ and $\mathrm{Cd}$ obtained in the water samples in this study were lower than that reported in River Benue, in Ologe Lagoon, and in River Niger respectively [6-8]. The values of $\mathrm{Pb}$ and $\mathrm{Cd}$ recorded in water in this study also differs from the finding of other studies that reported lead beyond the permitted limits [9-13]. Moreso, the concentrations of $\mathrm{Pb}$ and $\mathrm{Cd}$ in the sediment, silver catfish (Chrysichthys nigrodigitatus) and brackish water prawn (Macrobrachium macrobrachion) in this study did not exceed the WHO recommended maximum permissible limit of $\mathrm{Pb}$ and $\mathrm{Cd}$ in sediment $\left(<20 \mu \mathrm{gg}^{-}\right.$ $\left.{ }^{1}\right)$,fish $\left(0.29 \mu \mathrm{gg}^{-1}\right)$ and shellfish $\left(0.10 \mu \mathrm{gg}^{-1}\right)$.The $\mathrm{Pb}$ and $\mathrm{Cd}$ obtained from sediment, fish and prawn in this study are lower than those reported earlier in similar fish species[14-15]. Studies have shown that concentration of cadmium beyond tolerable limits is toxic to kidney, results in neurological, hematological, behavioral, renal, cardiovascular and reproductive effects [16].

The level of chromium ( $\mathrm{Cr}$ ) in the water samples during the study was higher than the WHO recommended standard of $0.05 \mathrm{mgL}^{-1}$ of $\mathrm{Cr}$ in drinking water [17]. Elevated concentration of chromium in water may cause cancer to the consumers of the water without adequate treatment. The result of this study is similar to the finding of high $\mathrm{Cr}$ reported in River Benue [6]. However, the result differs from the findings that reported chromium below the recommended standard [12]. On the contrary, the levels of Cr detected in sediment, fish and prawn for the present study did not exceed the WHO maximum limit of $\left\langle 25 \mu \mathrm{gg}^{-1}, 0.1 \mu \mathrm{gg}^{-1}\right.$ and $0.08 \mu \mathrm{gg}^{-1}$ of $\mathrm{Cr}$ for sediment, fish and prawn respectively. Chromium is a key element in the metabolism of sugar in plants and animals and also regulate the rate played by insulin molecules in transporting glucose into the cells for glycolysis[18]. The concentration of copper $(\mathrm{Cu})$ in the surface water of both Ologe Lagoon and Badagry Creek were above WHO permissible value of $0.40 \mathrm{~mL}^{-1}$. This result was different from $\mathrm{Cu}$ reported in River Benue which was within the recommended standard [19].The concentration of copper in sediment during this study did not exceed recommended limit in sediment $\left(<30 \mu \mathrm{gg}^{-1}\right)$, but $\mathrm{Cu}$ level in the fish at both stations and prawn from Ologe Lagoon were above $0.4 \mu \mathrm{gg}^{-1}$ recommended limit. Copper is an essential element that facilitates the action of some enzymes in the body of humans [20].Other studies elsewhere also reported $\mathrm{Cu}$ concentration within the recommended standard $[10,13]$. The highest concentration of copper in this study may be attributed to the heap of wastes at these stations and leachates from the wastes that are washed directly into these water bodies.

The levels of zinc $(\mathrm{Zn})$ obtained in water sample, sediment, fish and prawn during this study, all exceeded WHO permissible limits. The permissible limit of zinc in water, sediment, fish and 
prawn respectively are $0.01 \mathrm{mgL}^{-1},<90 \mu g_{-}{ }^{1}, 5.0 \mu g_{-1}$ and $3.0 \mu g^{-1}$. Studies have shown that metals such as Zn bioaccumulate poorly in fish [12]. Zinc contamination could have effect on the hepatic distribution of other trace metals in fish.

Iron $(\mathrm{Fe})$ concentration detected during this study exceeded the recommended limits. World health organization recommended Fe levels are water $(5 \mathrm{mg} / \mathrm{l})$, sediment $\left(20 \mu \mathrm{gg}^{-1}\right)$, fish $\left(3 \mu \mathrm{gg}^{-1}\right)$ and prawn $\left(2 \mu \mathrm{gg}^{-1}\right)$. The concentration of iron recorded in fish and prawn during this study were higher when compared with those detected in Cynothriss amento and Gadus morhua respectively [20-21].This present findings could implies that the specimen bioaccumulate high $\mathrm{Fe}$ in their body. Iron is an essential component of haemoglobin which is responsible for oxygen transportation in the body. However, severe iron deficiency in human causes anaemia[17].

\section{CONCLUSION}

The study has shown that both water bodies are contaminated with heavy metals although more prominent in Ologe Lagoon. It could therefore be concluded that the two water bodies could still sustain the fish and the prawn but their consumption at present is a threat to human health. Therefore, there is an urgent need to properly manage and coordinate the activities of people within both stations by the appropriate agencies in order to ensure that runoff water will have minimal effect on Badagry creek and Ologe Lagoon.

\section{REFERENCES}

1. Onuoha PC, Nwankwo DI, Wim V. Diatoms of Tropical Eutrophic Lagoon. Journal of American Science. 2010; 6 (11): 452-456.

2. Akoachere JTK, Oben PM, Mbivnjo BS, Ndip LM, Nkwelang G, Ndip RN. Bacterial indicators of pollution of the Doula Lagoon, Cameroon: Public health implications. African Health Sciences.2008; 8:85-89.

3. Akaahan TJA, Araoye PA, Azua ET. Physico-chemical characteristics and macro invertebrates of River Benue at Makurdi, Benue State, Nigeria. International Journal of Science and Technology.2014; 2(6):32- 39.

4. Uysal K, Emre Y, Kose E. The determination of heavy metal accumulation ratios in muscle, skin and gills of some migratory fish species by inductively coupled plasmaoptical emission spectrometry (ICP-OES) in Beymelek Lagoon (Antalya/Turkey). Microchemistry Journal.2008; 90:67-70.

5. APHA. Standard Methods for the Examination of Water and Wastewater, $21^{\text {stedition }}$ American Public Health Association. Washington DC.2005;1368p. 
International Journal of Agriculture and Environmental Research

ISSN: 2455-6939

Volume: 06, Issue: 03 "May-June 2020"

6. Eneji IS, Sha'Ato R, Annune PA. An assessment of heavy metal loading in River Benue in Makurdi metropolitan area North central Nigeria. Environmental Monitoring and Assessment. 2011; pp.159-165.

7. Ndimele PE, Kumolu-Johnson CA. Some Aspects of the Physicochemistry and Heavy Metal Content of Water, Sediment and Cynothriss amento (Regan, 1917) from Badagry Creek, Lagos, Nigeria. Trends in Applied Science Research. 2012; 7: 724-736.

8. Olatunji OS, Osibanjo O. Determination of selected heavy metals in inland fresh water of lower River Niger drainage in North Central Nigeria. African Journal of Environmental Science. Technology. 2012; 6(10):403-408.

9. Hong AH, Law PL, Selaman OS. Physico chemical quality assessment of pollutants in River Benue water in Jimeta/Yola Metropolitan. Adamawa State North Eastern Nigeria. American Journal of Environmental Protection.2014; 3(2):90-95.

10. Wangboje OM, Ekundayo OT. Assessment of heavy metals in surface water of the Ikpoba Reservoir, Benin City, Nigeria. Nigeria Journal of Technology. 2013; 32(11): 6166.

11. Asante F, Agbeko E, Addae G, Quainoo AK. Bioaccumulation of heavy metals in water, sediments and tissues of some selected fishes from Red Volta. Nangidi in the upper East Region of Ghana. British Journal of Applied Science and Technology.2014; 4(4):594603.

12. Akintujoye JF, Anumudu CI, Awosode HO. Assessment of heavy metals residues in water, fish tissue and human blood from UbetiWaon: Delta State, Nigeria. Journal of Applied Science and Environmental Management.2013; 17(2):291- 297.

13. Aderinola OJ, Clarke EO, Olarinmoye OM, Kusemiju V, Anetekhai MA. Heavy metals in surface waters,sediments, fish and periwinkles of Lagos Lagoon. American Eurasian Journal of Agriculture and. Environmental Sciences,2009: 5(5):609-617.

14. Chindah AC, Sibeudu OC. Levels of hydrocarbons and heavy metals in sediment and a Decapod crustacean (Ucatangeri) in Bonny/New Calabar river estuary, Niger Delta. Ochroma Srodowis kaIzasobow Naturals. 2003; 25/26pp.

15. Eja ME, Ogri ORA, Arikpo GE. Bioconcentration of heavy metals in surface sediments from the Great Kwa Rivers Estuary, Calabar, South Eastern Nigeria. Journal of Nigeria Environmen and Society.2003, 2:247-256. 
16. FAO/WHO. Joint FAO/WHO food standards programme codex committee on contaminants in foods. 5th Session, the Hague Netherlands, 21-25 March, 2011, ftp://ftp.fao.org/codex/ meetings/CCCF/cccf5/cf05_INF.pdf.

17. WHO. Drinking Water Guidelines available at http://103.whosea.org.tehifor/water.litm/, 2004;130 pp.

18. Mekuleyi GO, Joseph OO. Levels of heavy metals in Pseudotolithus elongatus from Badagry market, Nigeria. Turkish Journal of Aquatic Sciences. 2017; 32(4): 84-88.

19. Ugwu AI, Wakawa RJ, La'ah E, Olotu A. Spatial distribution of heavy metals in river Usuma sediments and study of factors impacting the concentration. IJRRAS.2012; 12 (2): 294-303.

20. Kumolu-Johnson CA, Ndimele PE, Akintola SL, Jibuike CC. Copper, zinc and iron concentrations in water, sediment and Cynothriss amento (Regan 1917) from Ologe Lagoon, Lagos, Nigeria: A preliminary survey. African Journal of Aquatic Science. 2010; 35: 87-94.

21. Eze SO, Ogbuehi GI. Assessment of heavy metals and polycyclic aromatic hydrocarbon concentration in some stockfish species sold in five major markets of Aba south, Abia state, Nigeria. European Journal of Pure and Applied Chemistry.2015; 2(1):1-7. 